PERSPECTIVES ON PRAGMATISM 



\section{PERSPECTIVES ON PRAGMATISM}

CLASSICAL, RECENT, AND CONTEMPORARY

Robert B. Brandom

HARVARD UNIVERSITY PRESS

Cambridge, Massachusetts

London, England

2011 
Copyright () 2011 by the President and Fellows of Harvard College

All rights reserved

Printed in the United States of America

\section{Library of Congress Cataloging-in-Publication Data}

Brandom, Robert.

Perspectives on pragmatism : classical, recent, and contemporary / Robert B. Brandom. p. cm.

Includes bibliographical references and index.

ISBN 978-0-674-05808-8 (alk. paper)

I. Pragmatism. I. Title.

B832.B73 2011

$144^{\prime} .3-\mathrm{dc} 22$

2011007667 
For Bruce Kuklick, mentor and friend, who as my undergraduate teacher at Yale introduced me to the excitement and discipline of intellectual history in general, and to the American pragmatists in particular. He inspired a lifelong philosophical journey, of which this work is just one report. 
